Uniwersytet im. Adama Mickiewicza, Poznań

\title{
Przedmiot prawa autorskiego. Przypadki graniczne
}

Pojęcie przedmiotu prawa autorskiego wydaje się, że zostało przez ustaz dnia 4 lutego 1994 r. o prawie autorskim i prawach pokrewnych ${ }^{1}$. Przepis ten zawiera bowiem ustawową definicję utworu. Zgodnie z nim, przedmiotem prawa autorskiego jest każdy przejaw działalności twórczej o indywidualnym charakterze, ustalony w jakiejkolwiek postaci, niezależnie od wartości, przeznaczenia i sposobu wyrażenia. Dodatkowo w ust. 2 tego przepisu ustawodawca zdecydował się na wyliczenie przedmiotów prawa autorskiego, ale - jak to słusznie się zauważa - ma ono charakter jedynie przykładowy. Przypomnijmy jednak, iż zgodnie z tym przepisem ,w szczególności przedmiotem prawa autorskiego są utwory: 1) wyrażone słowem, symbolami matematycznymi, znakami graficznymi (literackie, publicystyczne, naukowe, kartograficzne oraz programy komputerowe); 2) plastyczne $^{2}$; 3) fotograficzne; 4) lutnicze ${ }^{3}$; 5) wzornictwa przemysłowego; 6) architektoniczne, architektoniczno-urbanistyczne i urbanistyczne;

T.j. Dz. U. 2006, Nr 90, poz. 631 z późn. zm.

2 Zgodzić należy się z poglądem prezentowanym w doktrynie, iż „w grę wchodzi tu m.in. malarstwo, rysunek, grafika, rzeźba, performance, sztuka użytkowa, szata graficzna gazety, makieta". J. Barta, R. Markiewicz, w: J. Barta, M. Czajkowska-Dąbrowska, Z. Ćwiąkalski, R. Markiewicz, E. Traple, Komentarz do ustawy o prawie autorskim i prawach pokrewnych, Warszawa-Zakamycze 2005, s. 86 (dalej skrótowo Komentarz 2005).

${ }^{3} \mathrm{~W}$ pkt 4 wymienia się utwory lutnicze, co było przedmiotem ostrej krytyki w doktrynie, bo nie chodzi tu z pewnością o utwory na instrumenty smyczkowe, a o same instrumenty lutnicze. ,Wydaje się wręcz niemożliwe dopatrzenie się w rezultatach pracy lutników cech twórczości (zwłaszcza indywidualności), gdyż kształt (forma) i wygląd tych instrumentów jest powszechnie znany i nie podlega twórczym zmianom. W tej sytuacji uznanie takich instrumentów za przedmiot ochrony może sugerować, bądź ochronę przedmiotu materialnego jako rękodzieła artystycznego, bądź ochronę ze względu na szczególne właściwości instrumentu (jakość dźwięku)”. Szerzej J. Barta, R. Markiewicz, System prawa prywatnego, t. 13: Prawo autorskie, red. J. Barta, s. 30. 
7) muzyczne i słowno-muzyczne; 8) sceniczne, sceniczno-muzyczne, choreograficzne i pantomimiczne; 9) audiowizualne (w tym filmowe). Powyższa definicja ustawowa nie rozstrzyga jednak jednoznacznie przypadków granicznych tzn. takich, w których niski poziom twórczości powoduje istotne wątpliwości czy daną kategorię można zaliczyć do grupy utworów ${ }^{4}$. Przedmiotem niniejszego opracowania jest próba wyznaczenia granicy, pomiędzy utworami a przedmiotami nie chronionymi prawem autorskim, właśnie ze względu na zbyt niski stopień twórczości.

Jak z powyższego wynika, przedmiotem prawa autorskiego są jedynie dobra o charakterze niematerialnym, intelektualnym ${ }^{5}$. Przy czym - jak to wyraźnie podkreślił Sąd Najwyższy w wyroku z dnia 5 marca 1971 r. ${ }^{6}$ - o powstaniu prawa autorskiego nie decyduje stopień wartości opracowanego dzieła. Nawet niewielkie znaczeniowo opracowania, byleby cechował je element twórczości autora, mogą stanowić przedmiot ochrony autorskiej w rozumieniu art. 1 prawa autorskiego. Nader istotne w tym stanie rzeczy, jawi się odszukanie owych cech twórczych i indywidualnych. Nie każda bowiem przeróbka czy modyfikacja uchodzić będzie za działanie autorskie. Tak jest m.in. w sytuacji, gdy zmiany te mają jedynie charakter techniczny i drugorzędny. W oparciu o tezę wyżej przedstawionego orzeczenia SN stwierdzić można, iż linia graniczna pomiędzy tymi dwoma płaszczyznami przebiega w miejscu, gdzie odnajdziemy w dokonanych zmianach takie elementy, które ocenione zostaną jako mające znaczenie - choćby niewielkie - artystyczne czy naukowe ${ }^{7}$.

Warto w tym miejscu przypomnieć, aby wynik działań człowieka zyskał miano przedmiotu prawa autorskiego, spełnione muszą zostać łącznie trzy przesłanki. Chodzi tu o: przejaw działalności twórczej, indywidualny

4 J. Barta, M. Czajkowska-Dąbrowska, Z. Ćwiąkalski, R. Markiewicz, E. Traple, Komentarz 2005, op. cit., s. 85.

5 J. Sobczak, Prawo autorskie i prawa pokrewne, Warszawa-Poznań 2000, s. $36-37$.

${ }^{6}$ Wyrok SN z dnia 5 marca 1971 r. CR 593/70 - opublikowany w OSPiKA 1972/7-8, poz. 135 - zachowujący aktualność także pod rządem nowego prawa autorskiego.

Tak SN w przywołanym powyżej orzeczeniu; por. także glosę M. Czajkowskiej opublikowaną w tym samym miejscu; zob. także J. Sobczak, Prawo autorskie..., op. cit., s. 37; tenże, Prawo prasowe. Podręcznik akademicki, Warszawa 2000, s. 84-85 oraz M. Szaciński, Wktad twórczy jako przesłanka dzieła chronionego prawem autorskim, PiP 1993, z. 2, s. 50-53; tenże, Wkład twórczy jako przesłanka dzieła chronionego prawem autorskim, N.P. 1982, z. 5-6. 
charakter takiej pracy, wreszcie o ustalenie w jakiejkolwiek postaci ${ }^{8}$. $\mathrm{Z}$ punktu widzenia niniejszego opracowania dwie pierwsze przesłanki mają szczególnie istotne znaczenie. Otóż w doktrynie przejaw działalności twórczej nazywa się oryginalnością, natomiast dla pojęcia ,indywidualny charakter" rezerwuje się termin indywidualność. Oba pojęcia składają się na pojęcie twórczości ${ }^{9}$. Pierwsze z wyżej podanych pojęć, choć jego definicji nie można odnaleźć $\mathrm{w}$ ustawie, utożsamiany jest z powstawaniem czegoś niepowtarzalnego i niebanalnego ${ }^{10}$ „Uważa się [...], że oryginalne jest wszystko to, co zawdzięcza swe powstanie samodzielnemu wysiłkowi twórczemu. W takim ujęciu oryginalność pokrywa się z tzw. nowością subiektywną (podmiotową), ponieważ można «stworzyć» tylko to, czego się nie znało uprzednio. Oryginalne jest to, co bierze swój początek w umyśle twórcy. W dążeniu do pewnego zobiektywizowania tej cechy w doktrynie prawa autorskiego próbowano posłużyć się kryterium unikalności, która [...] polega na tym, że istnieje wysoki stopień prawdopodobieństwa, iż nikt inny samodzielnie nie stworzy identycznego utworu. [...] Odwołanie się do samodzielnej twórczości oznacza stwierdzenie, że to, co zostało stworzone, nie było uprzednio znane w takiej samej postaci (cecha nowości) oraz że mamy do czynienia z jakimś obiektywnie uchwytnym rezultatem samodzielnej twórczości, tj. że twórca istotnie wzbogacił dotychczasowy stan rzeczy nowymi elementami (oryginalność). Należy zwrócić uwagę na to, że wedle ustawy ochronie podlega każdy [...] przejaw twórczości. To określenie należy łączyć nie tylko z samym utworem, lecz także z działalnością twórczą, która może przybierać różne rodzaje, owocować różnymi wynikami i w różny sposób się przejawiać" $" 11$.

Z kolei w przypadku przesłanki indywidualnego charakteru w literaturze panuje przekonywujący pogląd, iż pomocne może okazać się tu skorzystanie z koncepcji statystycznej jednorazowości autorstwa M. Kumera. Zgodnie z nią, dla wykazania owej jednorazowości trzeba udzielić nega-

8 „Ustalenie to [...] takie uzewnętrznienie utworu, które umożliwiąjego percepcję przez osoby trzecie, chociażby miał jeszcze postać nieukończoną" - tak. M. Poźniak-Niedzielska, w: System, op. cit., s. 12.

9 Patrz szerzej J. Barta, M. Czajkowska-Dąbrowska, Z. Ćwiąkalski, R. Markiewicz, E. Traple, Komentarz do ustawy o prawie autorskim i prawach pokrewnych, ABC, Warszawa 1995, s. 48-49 oraz J. Sobczak, Prawo autorskie..., op. cit., s. 39-42.

10 J. Sobczak, Podstawy prawa autorskiego, Poznań 1995, s. 18.

11 Tak M. Późniak-Niedzielska, w: System..., op. cit., s. 8-9. 
tywnej odpowiedzi na następujące dwa pytania. Po pierwsze, „,czy wcześniej takie dzieło powstało”, a po drugie „,czy jest statystycznie prawdopodobne wytworzenie go w przyszłości” ${ }^{12}$. Warto też odnotować pogląd, iż „wymaganie to [...] stanowi wyraźne odesłanie do osoby twórcy, stanowiąc pomost łączący pewien byt niematerialny z określoną osobą w sposób uzasadniający węzeł autorstwa. Nie oznacza to wcale, że utwór musi koniecznie odzwierciedlać cechy indywidualności twórcy, ale że sam przez się musi wyróżniać się od innych takich samych przejawów działalności twórczej w sposób świadczący o jego swoistości, oryginalności i tych wszystkich właściwościach, które sprawiają, że w większym czy mniejszym stopniu jest on niepowtarzalny i nieposiadający swojego wiernego odpowiednika w przeszłości"13.

Na marginesie jedynie wypada zauważyć, iż na gruncie polskiej regulacji z 1926 r. formułującej tę przesłankę podobnie, bowiem jako ,przejaw działalności duchowej noszący cechy osobistej twórczości"14 ${ }^{\text {W orzecz- }}$ nictwie SN wyraźnie podkreślano, iż przedmiotem ochrony prawnej z mocy ustawy o prawie autorskim jest wszelkie dzieło piśmiennictwa będące wypływem indywidualnej twórczości bez względu na jej zakres i wartość ${ }^{15}$. W tym nurcie pozostają także inne orzeczenia $z$ tego okresu, które zachowują przynajmniej częściową aktualność także pod rządem obecnej ustawy. Przypomnieć tu zatem należy orzeczenie Sądu Najwyższego z 31.03.1938 r., stwierdzające, iż „każda twórczość umysłowa bez względu na to, czy chodzi o twórczość opartą na ściśle samoistnym pomyśle, czy też opartą na naśladownictwie już istniejących dzieł, doznaje ochrony prawnej, byleby w swoim ostatecznym wyniku, w swojej zewnętrznej formie wykazywała znamiona wyróżniające ją od innych dzieł osobliwością pomysłu i umiejętnością tematu"16. Tak więc w każdym przypadku odnalezienia powyżej sygnalizowanych przesłanek mowa będzie o twórczości, a więc o przedmiocie prawa autorskiego. Praca twórcza

12 J. Barta, M. Czajkowska-Dąbrowska, Z. Ćwiąkalski, R. Markiewicz, E. Traple, Komentarz, op. cit., s. 49.

13 Ibidem.

14 Cyt. za J. Sobczak, Podstawy..., op. cit., s. 19.

15 Zob. orzeczenie SN z 8.11.1932 r., IK 1092/32, Zb. OSN (ZB. Urz. Karny) 1933, nr 1, poz. 7, teza opublikowana także w J. Barta, R. Markiewicz, Prawo autorskie. Przepisy. Orzecznictwo. Umowy międzynarodowe, ABC, Warszawa 1997, s. 672 oraz J. Sobczak, Prawo autorskie, op. cit., s. 40.

16 Orzeczenie SN z 31.03.1938 r., sygn. akt C II 2531/37; cytowana teza została zaczerpnięta z J. Barta, R. Markiewicz, Komentarz 2005, op. cit., s. 673. 
bowiem przejawiać winna się w inwencji twórczej, samodzielności i oryginalności opracowania ${ }^{17}$. Nie pozbawia tej cechy pracy autora - jak słusznie zauważył SN w orzeczeniu z $18.11 .1960 \mathrm{r}^{18}{ }^{18}$ - nawet wykorzystanie przez niego pewnych źródeł, pod warunkiem wszakże, iż nie będzie to oznaczać sprowadzenia owej działalności do mechanicznego przepisywania treści. Przy czym o dziele, a więc przedmiocie prawa autorskiego, mówić można już wtedy, gdy w jego treści widoczne jest ,piętno osobistej twórczości osoby dokonującej tego opracowania bez względu na jego poziom"19.

$\mathrm{Na}$ marginesie warto odwołać się do rozmaitych koncepcji budowy utworów. W piśmiennictwie wyróżnia się co najmniej dwie teorie obrazujące poruszane zagadnienie. Po pierwsze mowa tu o koncepcjach strukturalnych, a w szczególności o warstwowej budowie utworu oraz o teoriach integralnych. Według pierwszego z prezentowanych poglądów autorstwa J. Kohlera, następnie zmodyfikowanych i wzbogaconych przez A. Kopffa ${ }^{20}$, każde dzieło zbudowane jest z możliwych do wyodrębnienia warstw, które łącznie składają się na przedmiot prawa autorskiego. Przy czym doszukać można się trzech warstw: obrazu zindywidualizowanego, formy wewnętrznej oraz formy zewnętrznej. Obraz zindywidualizowany to „koncepcja twórcza zawierająca wszystko co składa się na rzeczową, psychologiczną i ideologiczną treść dzieła sztuki ukształtowaną indywidualnie, a więc zgodnie z przekonaniami i predyspozycjami twórczymi artysty"21. Z kolei forma wewnętrzna to „środki, które służą obleczeniu obrazu zindywidualizowanego w kształt artystyczny"22, wreszcie forma zewnętrzna to „ogół artystycznych środków przedstawieniowych oddziałujących na zmysły odbiorców" 23 . Druga teoria tzw. integralnej budowy utworu repre-

17 Tak SN w orzeczeniu z 5.03.1970 r., sygn. akt II CR 686/70, OSN 1971, nr 12, poz. 231, PIP 1972, nr 7, s. 132 z glosą M. Poźniak-Niedzielskiej; tezę tę zaprezentowano także w J. Barta, R. Markiewicz, Komentarz 2005, op. cit., s. 675; por. także wyrok NSA w Lublinie I SA/Lu 274/97, nie publikowane, dostępne w komputerowej bazie danych LEX.

18 Orzeczenie SN z 18.11.1960 r., sygn. akt I CR 234/60, opublik. w OSN 1961, nr 4, poz. 124 .

19 Por. orzeczenie SN z 21.06.1968 r., sygn. akt I CR 206/69, OSN 1969, nr 5, poz. 94.

20 Zob. A. Kopff, Dzieło sztuk plastycznych i jego twórca w świetle przepisów prawa autorskiego, Kraków 1961, s. 47 i n.

21 Ibidem.

22 Ibidem.

23 Ibidem, s. 153; autor cytowany także przez E. Wojnicką, op. cit., s. 11-12. 
zentowana w literaturze głównie przez J. Błeszyńskiego ${ }^{24}$ opiera się na założeniu, iż elementy treści i formy składają się na utwór i bezprzedmiotowym zabiegiem jest wyodrębnianie poszczególnych warstw utworu ${ }^{25}$.

Jak z powyższego wynika, ,nieostrość przyjętych w ustawie kryteriów przyznania autorskoprawnej ochrony, który to problem można uznać za immanentny dla prawa autorskiego, prowadzi bezpośrednio do wzrostu znaczenia orzecznictwa. W razie sporu co do tego, czy dany rezultat pracy można traktować jako przedmiot prawa autorskiego poszukuje się rozstrzygnięć wydanych w podobnych przypadkach, ewentualnie sformułowanych przez sądy wskazówek, które w danym przypadku mogłyby znaleźć zastosowanie. Nie ulega przy tym wątpliwości - i orzecznictwo to potwierdza - że o tym czy wytwór niematerialny jest utworem decyduje stan faktyczny: wolą stron nie można rezultatowi pracy człowieka nadać statusu przedmiotu prawa autorskiego"26.

Zważywszy na powyższe należy przyjrzeć się judykaturze dotyczącej owych przypadków, gdy istnieją poważne wątpliwości, czy wytwór człowieka może być uznany za dzieło w rozumieniu prawa autorskiego, czy też nie.

I tak w wyroku z dnia 9 listopada 2006 r. Sąd Apelacyjny w Poznaniu ${ }^{27}$ zauważył, iż nie jest utworem w rozumieniu prawa autorskiego opracowanie stanowiące jedynie zastosowanie nawet wysokospecjalistycznej wiedzy technicznej, jeżeli jego treść jest z góry zdeterminowana obiektywnymi warunkami i wymaganiami technicznymi oraz charakterem realizowanego (rozwiązywanego) problemu (zadania) technicznego. W wyroku z dnia 13 stycznia 2006 r. Sąd Najwyższy ${ }^{28}$ prezentuje pogląd, że „nie może być uznany za utwór i objęty ochroną prawa autorskiego taki przejaw ludzkiej aktywności umysłowej, któremu brak cech dostatecznie indywidualizujących, to jest odróżniających go od innych wytworów podobnego rodzaju i przeznaczenia”. Można też tu przywołać wyrok Sądu Najwyższego z 27 lutego 2009 r. $^{29}$, gdzie zaprezentowano tezy, iż: ,pogląd, zgodnie

24 Zob. J. Błeszyński, Tłumaczenie i jego twórca $w$ polskim prawie autorskim, Warszawa 1973, s. 33 i n.

25 Por. także E. Wojnicka, op. cit., s. 12.

26 J. Barta, R. Markiewicz, w: System, op. cit., s. 17.

27 Wyrok z dnia 9 listopada 2006 r. Sądu Apelacyjnego w Poznaniu (sygn. akt I ACa 490/06), opublik. LEX nr 370747.

28 Wyrok SN z dnia 13 stycznia 2006 r., sygn. akt III CSK 40/05, opublik. LEX nr 298567.

29 Wyrok Sądu Najwyższego z 27 lutego 2009 r., sygn. akt V CSK 337/08, opublik. LEX nr 488738. 
z którym SIWZ [tj. Specyfikacja Istotnych Warunków Zamówienia - przyp. JS] nie stanowi utworu, lecz jest materiałem urzędowym naruszyła art. 1 ust. 1 i art. 4 pkt 2 prawa autorskiego przez błędną wykładnię tych przepisów. Oceniając stopień indywidualności określonego wytworu intelektu należy uwzględnić rodzaj dzieła. Inne przesłanki decydują w przypadku dzieła literackiego (np. poetyckość języka, dobór środków stylistycznych i wersyfikacji), inne zaś w odniesieniu do utworów o charakterze referencyjnym, jakim jest SIWZ. Dla oceny określonego dzieła referencyjnego przydatna jest koncepcja tzw. statystycznej jednorazowości, która zakłada badanie, czy takie samo lub bardzo podobne dzieło powstało już wcześniej oraz czy jest statystycznie prawdopodobne sporządzenie w przyszłości takiego samego dzieła przez inną osobę. Odpowiedź przecząca uzasadnia tezę o istnieniu cechy indywidualności dzieła"30.

W wyroku z dnia 7 listopada 2007 r. Sąd Apelacyjny w Poznaniu podkreślił, iż „stwierdzenie, że utwór stanowi przejaw «działalności twórczej», oznacza, że utwór powinien stanowić rezultat działalności o charakterze kreacyjnym. Przesłanka ta, niekiedy określana jako przesłanka «oryginalności» utworu, zrealizowana jest wówczas, gdy istnieje subiektywnie nowy wytwór intelektu. Ustalenie, że określona czynność (dzieło) ma charakter twórczy lub nie, nie należy do sfery zarzutów prawa materialnego, ale sfery ustaleń faktycznych, będących dopiero podstawą zastosowania prawa" 31 .

Na uwagę zasługuje także wyrok Sądu Najwyższego z dnia 30 czerwca 2005 r., gdzie podkreślono, iż okoliczność, że tzw. dzieła techniczne są rezultatem uzyskiwanym w ramach stałej działalności zawodowej autora, nie wyklucza ich z kręgu utworów w rozumieniu art. 1 ust. 1 ustawy z dnia 4 lutego 1994 r. o prawie autorskim i prawach pokrewnych ${ }^{32}$.

Dla porządku należy także odnotować poglądy doktryny w takich właśnie sprawach granicznych. I tak w ocenie M. Barczewskiego wyrażonej w glosie ${ }^{33}$ do wyroku Sądu Najwyższego z dnia 25 stycznia 2006 r., „ochrona prawnoautorska nie dotyczy działalności o charakterze odtwór-

30 Ibidem.

31 Wyrok z dnia 7 listopada 2007 r., sygn. akt I ACa 800/07.

32 Wyrok Sądu Najwyższego z dnia 30 czerwca 2005 r., sygn. akt IV CK 763/04, opublik. w LEX nr 176385, Biul. SN 2006/3, Wokanda 2006.

33 M. Barczewski, Glosa do wyroku Sąu Najwyższego z dnia 25 stycznia 2006 r., I CK 281/05 (opublik. GSP-Prz.Orz. 2007.4.4, OSNC 2006/5/92, Biul. SN 2005/9, OSP 2007/6 oraz w LEX nr 82950/1). 
czym bądź technicznym, polegającej na wykonywaniu czynności wymagających jedynie określonej wiedzy i sprawności oraz użycia określonych narzędzi, surowców i technologii".

Przywołać należy także stanowisko J. Barty i R. Markiewicza, iż „nie podlega autorskoprawnej ochronie - w naszym przekonaniu - rekonstrukcja utworu w tym zakresie, w jakim badacz odtwarza (często dzięki niewątpliwemu procesowi twórczemu) uprzednio istniejący utwór literacki, muzyczny czy architektoniczny. Podobne stanowisko - zdaniem tych autorów - wyrażono w orzeczeniu Sądu Najwyższego z 6.09.1937 r., w którym uznano, że «istnienie w utworze cech indywidualnych twórczości zależne jest od tego [...], czy jego utwór jest tylko odtworzeniem istniejącego już kształtu artystycznego». W innych jednak orzeczeniach SN przyjmował dyskusyjne stanowisko, według którego odtworzenie pierwotnej wersji utworu (badawcze ustalenie tekstu) może stanowić przedmiot prawa autorskiego" 34 .

Jednak zdaniem cytowanych powyżej autorów ,,podobna problematyka [jak w przypadku rekonstrukcji - przyp. JS] powstaje w przypadku kwalifikowania do kategorii utworów fotografii dzieł sztuki, zwłaszcza obrazów i rysunków. Dwa znane nam polskie orzeczenia sądowe dotyczące tej kwestii zgodnie udzielają tu negatywnej odpowiedzi ${ }^{35}$. Sąd w tej sprawie wypowiedział się, że istota barwnej reprodukcji fotograficznej obrazów zakłada w istocie (uwzględniając techniczne możliwości w zakresie wydajności zastosowanej techniki) oddanie konkretnego zestawu kolorystycznego bez jakiejkolwiek ingerencji w ich wewnętrzną charakterystykę. Ingerencja taka stanowiłaby przejaw interpretacji treści reprodukowanego malowidła, a tylko dokonanie interpretacji treści dawałoby pole dla twórczej działalności”36 . „Podobne stanowisko zajął Sąd Najwyższy - Izba Administracyjna, Pracy i Ubezpieczeń Społecznych w orzeczeniu z 26 czerwca 1998 r. ${ }^{37}$ Czytamy w nim: Według art. 1 ust. 2 pr. aut. utworem może być także fotografia, jeżeli jest «przejawem dzia-

34 Orzeczenie Sądu Najwyższego z 6.09.1937 r., opublik. w OSP 1938, poz. 381. Por. także niepubl. orzeczenie SN z 23.06.1936 r., 1K336/36 oraz niepublik. orzeczenie S.A. w Warszawie z 16.11.1993 r., I Atr 698/93.

35 Tak Sąd Apelacyjny w Warszawie w orzeczeniu z 5.07.1995 r., sygn. akt I Acr 453/95.

36 Patrz szerzej orzeczenie to cytowane jest ibidem, s. 81.

37 Orzeczenie Sądu Najwyższy - Izba Administracyjna, Pracy i Ubezpieczeń Społecznych z 26 czerwca 1998 r., I PKN 196/98, OSP 1999, p. 207 P, s. 577, z glosą T. Kuczyńskiego. 
łalności twórczej o indywidualnym charakterze». Tak sformułowana definicja zakłada, że przejaw działalności twórczej wtedy może być uznany za utwór, gdy nosi piętno właściwe danej jednostce, znamiona odróżniające go od innych. [...] W czynnościach powoda jako fotografa [renowatora] nie mieszczą się elementy twórcze, lecz odtwórcze. Jego obowiązkiem nie było bowiem wykonywanie zdjęć obrazów i innych przedmiotów sztuki w sposób oddający wrażenia artystyczne powoda czy też wyrażający jego wizję artystyczną, lecz wykonywanie zdjęć odtwarzających przy pomocy fotografii rzeczywisty stan zbiorów muzealnych i obiektów budowlanych" ${ }^{\text {38. }}$

Podsumowując te rozważania, należy przypomnieć, iż „w polskim orzecznictwie sądowym uznano za przedmiot prawa autorskiego m.in.: kolekcję afiszy lub ogłoszeń, katalogi, rozkłady kolejowe, książki kucharskie, wzory i formularze (orzeczenie SN z 8 listopada 1932 r., Zb. OSN 1933, poz. 7), informator o porcie (nie publ. orzeczenie $\mathrm{SN} \mathrm{z} 27$ marca 1965 r., I CR 39/65), instrukcję obsługiwania maszyny (orzeczenie SN z 25 kwietnia 1969 r., OSN 1970, poz. 15), instrukcję bhp (nie publ. orzeczenie SN z 23 lipca 1971 r., II CR 244/71), kompozycję z kwiatów (orzeczenie SN z 25 kwietnia 1973 r., OSN 1974, poz. 50), projekty dokumentacji technicznej, plany, zarysy, szkice, rysunki, modele i projekty (orzeczenie SN z 12 czerwca 1978 r., WiR 1978, nr 15, s. 13), wzór zdobniczy (orzeczenie SN z 20 kwietnia 1984 r., OSN 1984, poz. 188), projekt jachtu (nie publ. orzeczenie SN z 20 czerwca 1988 r., II CR 178/88), projekt znaku towarowego (orzeczenie SN z 23 czerwca 1989 r., PUG 1990, poz. 19) ${ }^{39}$. Z kolei do granicznych kategorii zalicza orzecznictwo, a w ślad za nim cytowani powyżej autorzy ,[...] takie (wytwory), których zaliczenie do utworów w rozumieniu ustawy o prawie autorskim jest szczególnie sporne ze względu na „niski poziom twórczości”. Chodzi tu m.in. o książki adresowe, telefoniczne, formularze, tabele, zestawienia programów telewizyjnych i radiowych, instrukcje obsługi, książki kucharskie, rozkłady jazdy, katalogi, cenniki, prospekty reklamowe, slogany reklamowe. Precyzyjne wskazanie zakresu ochrony takich wytworów nie jest możliwe. $Z$ reguły nie są utworami: programy telewizyjne, radiowe, teatralne, a także terminarze wydarzeń sportowych, bilety wstępu, bilety tramwajowe itd. Ogólnie można stwierdzić, że w przypadku wymienionych wytworów

38 Ibidem, s. 81.

39 Tak J. Barta, R. Markiewicz, Komentarz 2005, op. cit., s. 85. 
o wiele trudniej uzyskać poziom twórczości uzasadniający przyznanie im miana „utworów”; w tym też zakresie nie można odwołać się do swego rodzaju domniemania faktycznego - w praktyce dość często przyjmowanego w odniesieniu do innych wytworów intelektu - w myśl którego każdy z wytworów należący do wyżej wymienionych kategorii stanowi «utwór» w znaczeniu ustawy autorskiej" 40 .

W doktrynie zauważa się także te orzeczenia sądów powszechnych, które wypowiadają się w kwestii „nasilenia (stopnia) twórczości. Zwracają one m.in. uwagę na to, że na ochronę zasługuje każde dzieło ... byle tylko, przynajmniej pod względem formy, wykazywało pewne elementy twórcze, choćby minimalne" ${ }^{41}$. Cytowani autorzy powołują się na orzeczenie Sądu Apelacyjnego w Krakowie z 29.10.1997 r. ${ }^{42}$, w którym twierdzi się, że „o twórczym charakterze pracy autora można orzekać przede wszystkim na podstawie oceny właściwości, które przysługująjego utworowi $\mathrm{w}$ porównaniu $\mathrm{z}$ innymi produktami intelektualnymi; natomiast odwrócona inferencja, $\mathrm{tj}$. orzekanie o twórczym charakterze produktu intelektualnego na podstawie swoistych cech powstania, opiera się na kryteriach intersubiektywnie niesprawdzalnych i wskutek tego nieprzydatnych w ocenach prawnych. Cechy procesu powstawania wytworu intelektualnego nie są wystarczające do wyróżnienia go spośród innych rezultatów pracy intelektualnej, nie wskazują bowiem na jego swoistość (zindywidualizowaną postać) $\mathrm{w}$ stosunku do znanych, uprzednio wytworzonych produktów intelektualnych. Na gruncie zaś ocen, które uzasadniają udzielenie ochrony prawa autorskiego, nie wszystkie samodzielnie wytworzone produkty intelektualne korzystają z takiej ochrony, lecz tylko te spośród nich, które wykazują dostatecznie doniosłe różnice $\mathrm{w}$ porównaniu z uprzednio wytworzonymi produktami intelektualnymi" ${ }^{\prime 43}$.

Natomiast dla dopełnienia obrazu, warto tu przedstawić rozróżnienie przejawów działalności autorskiej w oparciu o treść art. 1 oraz art. 2, 3 i 11 ustawy o prawie autorskim i prawach pokrewnych, a mianowicie na utwory samoistne, samoistne ale inspirowane inną twórczością oraz

40 Ibidem, s. 85-86.

41 J. Barta, R. Markiewicz, w: System..., op. cit., s. 19 - autorzy powołują się na wyrok SN z 31.3.1953 r., sygn. akt II C 834/52, nie publik.

42 Orzeczenie Sądu Apelacyjnego w Krakowie z 29.10.1997 r., opublik. w Dobra osobiste, zbiór orzeczeń S.A. w Krakowie, oprac. B. Gawlik, Kraków 1999, s. 262 i n.

43 Ibidem. 
niesamoistne $e^{44}$. Te pierwsze charakteryzują się tym, iż autor w żadnym stopniu nie wspierał się na elementach innego dzieła. Zaliczyć tu możemy „utwory w pełni samoistne” a także te, które wprawdzie wykorzystują elementy pracy innych osób, ale tylko takie, które nie korzystają z ochrony autorskiej $^{45}$. W przypadku tej drugiej kategorii niewątpliwym impulsem do powstania nowego przedmiotu prawa autorskiego były inne dzieła, przy czym związek z dziełem inspirującym może być bliższy lub dalszy ${ }^{46}$. Wreszcie do trzeciej grupy zaliczyć trzeba te wszystkie wyniki pracy człowieka, których związek z innym utworami jest na tyle bliski, iż zawsze łączy się z ingerencją w cudzą domenę praw autorskich. W tej grupie wymienić po pierwsze należy opracowania (art. 2 ust. 1 ustawy) nazywane także dziełami zależnymi lub z drugiej ręki ${ }^{47}$. Pod tym pojęciem należy rozumieć w szczególności tłumaczenie, przeróbkę, adaptację, a rozporządzanie i korzystanie z nich zależy zawsze od zezwolenia twórcy utworu pierwotnego, chyba że autorskie prawa majątkowe do tego utworu wygasły $^{48}$. Po drugie, do dzieł niesamoistnych zalicza się także dzieła z zapożyczeniami, w których przytoczono cudze dzieło w całości lub w części $\mathrm{w}$,rozmiarach nie uzasadniających zastosowania przepisów o dozwolonym cytacie"49, a jednocześnie brak jest przesłanek do zakwalifikowania tego materiału do opracowań.

Jak się jednak okazuje, o czym już wyżej uprzedzałem, powyższe próby demarkacyjne o charakterze generalizacji, na tle konkretnej sprawy nadal zawodzą. Stąd też poprzestać trzeba wyłącznie na kazuistyce. Dla jej poszerzenia warto przyjrzeć się ciekawemu problemowi będącemu przedmiotem sprawy prowadzonej przez jeden z sądów okręgowych ${ }^{50}$,

44 Zob. szerzej J. Sobczak, Prawo autorskie..., op. cit., s. 58-66 oraz J. Barta, M. Czajkowska-Dąbrowska, Z. Ćwiąkalski, R. Markiewicz, E. Traple, op. cit., s. 51 i 59.

45 Por. art. 3 i 4 prawa autorskiego.

46 Patrz szerzej J. Sobczak, Prawo autorskie..., op. cit., s. 61 oraz B. Michalski, Dziennikarstwo a ograniczenia praw autorskich, Łódź 1998, s. 33-35.

47 Szerzej na ten temat J. Sobczak, Prawo autorskie..., op. cit., s. 60-61 oraz J. Barta, M. Czajkowska-Dąbrowska, Z. Ćwiąkalski, R. Markiewicz, E. Traple, op. cit., s. 59.

48 Tak art. 2 ust. 2 prawa autorskiego - szerzej na temat opracowań E. Wojnicka, Autorskie prawa zależne, Łódź 1990, passim).

49 J. Barta, M. Czajkowska-Dąbrowska, Z. Ćwiąkalski, R. Markiewicz, E. Traple, op. cit., s. 59.

50 Proces nie został do momentu złożenia artykułu do druku prawomocnie zakończony. Nie podaje się konkretnej sygnatury i wskazania, który sąd rozstrzygał tę sprawę. $Z$ punktu widzenia niniejszego opracowania nie mają znaczenia personalia, a jedynie istota problemu. 
w której próbowano rozstrzygnąć czy modele żaglowców są utworami w rozumieniu prawa autorskiego. Stan faktyczny przedstawiał się następująco. Powód wykonał model w skali 1:50 galeonu „Rycerz św. Jerzego", pochodzącego z roku 1627, na podstawie własnej wizji stworzonej w oparciu o opisy literackie, dostępne obrazy, ryciny, drzeworyty oraz dane techniczne obiektu zamieszczone w czasopiśmie „Morze”. Stworzony w ten sposób model zbudowany z różnych gatunków drewna, zawierał właściwe dla tego typu konstrukcji elementy takie jak ornamenty, tralki, działa, okna. Kolejny model, którego dotyczy niniejsze postępowanie tj. model w skali 1:30 fregaty „Berlin,” wykonany został w oparciu o plan generalny (zakupiony przez powoda na wyprzedaży) oraz wiedzę wykonującego na temat epoki, a wreszcie z uwzględnieniem jego doświadczania modelarskiego przejawiającego się charakterystyczną dla tego modelarza techniką barwienia lin i żagli, umieszczania nitów. W tym przypadku powód umieścił element wedle własnego pomysłu tj. herb Berlina. Następnie strony zawarły „umowę kupna - sprzedaży”, której przedmiotem była sprzedaż egzemplarza modelu okrętu żaglowego „Fregata Berlin” wykonanego przez sprzedającego jego własnym staraniem i na jego własny koszt. Wreszcie powód zawarł z pozwanym umowę dotyczącą wykonania modelu w skali 1:40 galeonu „Wappen v. Hamburg”, której przedmiotem było wykonanie ww. żaglowca w skali 1:40, długości ok. $140 \mathrm{~cm}$, wykonanego w całości z drewna mahoniowego, nitowanego drutem miedzianym oraz wyposażonego w dokładne odwzorowanie rzeźbienia drewnianego. Model ten stworzony został w oparciu o liczne źródła, takie jak opis zamieszczony w książce Wolfganga Quingera Vapenn von Hamburg, trzy wystawione modele tej jednostki, które powód obserwował podczas pobytów studialnych w muzeum w Hamburgu. Przy czym dodać trzeba, że większość oryginalnej dokumentacji tego statku, w szczególności w zakresie dekoracji została zniszczona. Powód także w tym przypadku dodał własne detale np. szalupę ratunkowa, kule armatnie wykonane ze śrutu ołowianego, przyrządy do czyszczenia luf armatnich, Pegaza. Także w tym przypadku takie fragmenty statku jak olinowanie, nity, ożaglowanie wykonane są charakterystyczną dla kunsztu modelarskiego powoda manierą.

Nie ma wątpliwości, iż w tym przypadku obserwujemy próbę odtworzenia $\mathrm{w}$ odpowiednio pomniejszonej skali istniejących $\mathrm{w}$ rzeczywistości żaglowców. Jednak właśnie pomniejszenie skali powoduje, iż wykonawca musi dokonać istotnych czynności intelektualnych, które w rezultacie oczywiście przybierają postać obróbki technicznej. W oparciu o wyżej prezentowane poglądy judykatury i doktryny (trzeba przyznać nie zawsze 
jednolite - zwłaszcza, gdy chodzi o jednostkowe sprawy) stwierdzić można, iż linia graniczna pomiędzy tymi dwoma płaszczyznami przebiega w miejscu, gdzie odnajdziemy w dokonanych zmianach takie elementy, które ocenione zostanąjako mające znaczenie - choćby niewielkie.

Oczywiście w przedmiotowej sprawie istniały w rzeczywistości statki - pierwowzory. $Z$ akt sprawy wynika, że istnieją również modele wytworzone w odpowiednio pomniejszonej skali. Ale przecież nie identyczne. W ocenianych przypadkach dostrzegać należy ów rezultat samodzielnej twórczości o czym przekonują takie elementy, jak m.in. tworzenie własnej autorskiej wizji okrętów (w oparciu o wiele różnych źródeł) dobór materiałów (rodzaje drewna i ich kolorystyka), ręczne tworzenie poszczególnych elementów, specyficzne metody barwienia ożaglowania i olinowania, itp. Powstało dzieło nowe, które można zakwalifikować do kategorii dzieł plastycznych. Nie mamy tu bowiem do czynienia z opracowaniem, stanowiącym jedynie zastosowanie wysokospecjalistycznej wiedzy technicznej, w którym treść jest z góry zdeterminowana obiektywnymi warunkami i wymaganiami technicznymi oraz charakterem realizowanego (rozwiązywanego) problemu (zadania) technicznego.

Z kolei w przypadku konieczności wykazania istnienia przesłanki indywidualnego charakteru dzieła, warto - jak już wyżej wspomniano - skorzystać z koncepcji statystycznej jednorazowości M. Kumera. Przypomnijmy, że zgodnie z nią, dla wykazania owej jednorazowości trzeba udzielić negatywnej odpowiedzi na następujące dwa pytania. Po pierwsze, „,czy wcześniej takie dzieło powstało”, a po drugie „,czy jest statystycznie prawdopodobne wytworzenie go w przyszłości" ${ }^{51}$. Gdy chodzi o pierwsze pytanie, to odpowiedź winna być właśnie negatywna. Owszem istniał w przeszłości przecież żaglowiec (w skali 1:1), ale działania powoda polegają na stworzeniu dzieła w odpowiednio pomniejszonej skali. Co jednak niezwykle istotne, powód nie dokonuje tu mechanicznego odtworzenia oryginału, bo owa skala narzuca inne problemy. Wytwór działalności powoda nie ma przecież pływać, jego wewnętrzna konstrukcja nie ma nic wspólnego z technicznymi rozwiązaniami znanymi z budowy statku. Co więcej istnieją podobne modele. Ale dzieła wykonane przez powoda są nacechowane wyraźnym piętnem autora. Działania te w istocie przypominają tworzenie realistycznego obrazu utrwalającego pływający orygi-

51 Cytaty za J. Barta, M. Czajkowska-Dąbrowska, Z. Ćwiąkalski, R. Markiewicz, E. Traple, op. cit., s. 49. 
nał (tylko, że dzieło ma charakter przestrzenny). A przecież w takim przypadku nikt nie kwestionowałby, iż mamy do czynienia z utworem plastycznym. Odpowiedź na drugie pytanie z „testu” Kumera również wydaje się być negatywna, a to z uwagi na osobiste piętno twórcy widoczne $\mathrm{w}$ prezentowanych modelach. Wydaje się zatem, że w niniejszej sprawie mamy do czynienia z utworami plastycznymi, dziełami inspirowanymi. Niewątpliwie bowiem impulsem dla stworzenia każdego z opiniowanych modeli był właściwy oryginał żaglowca.

Przy czym z pewnością nie każdy model statku prezentowany w wybranej skali za takie dzieło będzie uchodzić. Podobnie zresztąjak w przypadku fotografii. Jak to wyżej próbowano wykazać, nie każda działalność osoby wykonującej zdjęcie fotograficzne uchodzić będzie za przejaw działalności twórczej, podobnie jak nie każda rekonstrukcja. Wyobrazić bowiem można sobie przypadki, gdy modelarz składa uprzednio przygotowane części przez kogoś innego. Natomiast jeżeli wykonawca takiego modelu tworzy dzieło w oparciu o własną wizję stworzoną o liczne źródła (opisy techniczne, ryciny, malowidła itp.), gdy w procesie budowy wykorzystuje się specyficzne metody, techniki (które oczywiście same w sobie nie podlegają autorskoprawnej ochronie), widoczne jest w takich wytworach niepowtarzalne piętno twórcy.

Oczywiście podzielić należy przytoczony powyżej pogląd, iż „ochrona prawnoautorska nie dotyczy działalności o charakterze odtwórczym bądź technicznym, polegającej na wykonywaniu czynności wymagających jedynie określonej wiedzy i sprawności oraz użycia określonych narzędzi, surowców i technologii”, ${ }^{2}$. Ale wydaje się, że opisywana działalność powoda nie miała charakteru odtwórczego bądź technicznego, lecz właśnie twórczy. Nie mamy tu też do czynienia z prostą rekonstrukcją, ale tworzeniem - przyznajmy - realistycznej, ale własnej (indywidualnej) wizji danego żaglowca. Na koniec należy też zgodzić się ze stanowiskiem judykatury, a mianowicie, iż oceniając stopień indywidualności określonego wytworu intelektu należy uwzględnić rodzaj dzieła. Inne przesłanki decydują w przypadku dzieła literackiego (np. poetyckość języka, dobór środków stylistycznych i wersyfikacji), inne zaś w odniesieniu do utworów o charakterze referencyjnym, inne zaś w przypadku dzieł o charakterze technicznym ${ }^{53}$.

52 M. Barczewski, op. cit.

53 Tak wyrok Sądu Najwyższego z 27 lutego 2009 r., sygn. akt V CSK 337/08, LEX nr 488738. 


\section{Summary}

This study attempts to determine borderline between works and products which are not protected by copyright law on account of thesufficient degree of creativity involved. The legal definition is stipulated by Art. 1 of the Act on Copyright and Related Rights of February 4, 1994, but it does not provide a definitivefferentiation in certain borderline cases, that is whenever a low level of creativity raises substantial doubts as ther to include a given category in a group of works. 
